\title{
The Evolution of Insulin Glargine and its Continuing Contribution to Diabetes Care
}

\author{
Rolf Hilgenfeld • Gerhard Seipke • Harald Berchtold • \\ David R. Owens
}

Published online: 28 May 2014

(C) The Author(s) 2014. This article is published with open access at Springerlink.com

\begin{abstract}
The epoch-making discovery of insulin heralded a new dawn in the management of diabetes. However, the earliest, unmodified soluble insulin preparations were limited by their short duration of action, necessitating multiple daily injections. Initial attempts to protract the duration of action of insulin involved the use of various additives, including vasoconstrictor substances, which met with limited success. The subsequent elucidation of the chemical and three-dimensional structure of insulin and its chemical synthesis and biosynthesis allowed modification of the insulin molecule itself, resulting in insulin analogs that are designed to mimic normal endogenous insulin secretion during both fasting and prandial conditions. Insulin glargine was the first once-daily, long-acting insulin analog to be introduced into clinical practice more than 10 years ago and is specifically designed to provide basal
\end{abstract}

Electronic supplementary material The online version of this article (doi:10.1007/s40265-014-0226-4) contains supplementary material, which is available to authorized users.

R. Hilgenfeld $(\square)$

Institute of Biochemistry, Center for Structural and Cell Biology in Medicine and Center for Brain, Behavior and Metabolism, University of Lübeck, Ratzeburger Allee 160, 23538 Lübeck, Germany

e-mail: hilgenfeld@biochem.uni-luebeck.de

\section{R. Hilgenfeld}

Shanghai Institute of Materia Medica, Shanghai, China

G. Seipke $\cdot$ H. Berchtold

Sanofi-Aventis Deutschland GmbH, Frankfurt am Main, Germany

D. R. Owens

Diabetes Research Group, Institute of Life Sciences College of Medicine, Swansea University, Swansea, Wales insulin requirements. It has a prolonged duration of action and no distinct insulin peak, making it suitable for oncedaily administration and reducing the risk of nocturnal hypoglycemia that is seen with intermediate-acting insulins. Insulin glargine can be used in combination with prandial insulin preparations and non-insulin anti-diabetic agents according to individual requirements.

\section{Introduction}

\subsection{The Pre-Insulin Era}

Prior to the 1920s, the prognosis for people with insulinrequiring diabetes mellitus was very poor, with limited treatment options being available and high resultant morbidity and mortality, particularly in children and young adults [1]. Generally, confirmation of the diagnosis of diabetes in this 'pre-insulin' era meant eventual coma and subsequent death, often within 2 years of diagnosis [2]. At this time, physicians had to manage the disease through dietary modification alone, with some affected individuals being restricted to a diet with an almost negligible carbohydrate intake in a bid to control blood glucose levels [35]. In such circumstances, the benefit of such 'starvation' diets, involving repeated fasting and prolonged undernourishment, was relatively short-lived, providing only a modest extension of life [4]. Furthermore, there was little or no evidence to support longer-term efficacy benefits of undernourishment therapy, which was accompanied by a risk of infection, inanition, and poor quality of life [4]. However, such an approach would have improved the metabolic status of those with 'non-insulin-dependent' diabetes, which was not recognized as a separate entity until the mid-1930s and so this differentiation between 
diabetes types could not be used in treatment decisions at the time [6]. Indeed, dietary intake continues to be a mainstay of the management of type 2 diabetes mellitus (T2DM), taking on increased importance as obesity has become an increasing problem worldwide.

The magnitude of the discovery of insulin must therefore be viewed in the context of a disease that resulted in rapid deterioration and death. The eventual isolation and purification of insulin in a series of relatively crude experiments in the early 1920s heralded a new dawn for the management of diabetes, providing hope for the first time to all those people suffering from this debilitating disease. The pivotal discovery of insulin at the University of Toronto built on the work of earlier scientists, culminating in the development of an effective pancreatic extract (Fig. 1).

\subsection{The Discovery of Insulin}

Diabetes has been known about for millennia, with the first known description of symptoms allied to diabetes and suggested treatment written circa $1500 \mathrm{BC}$ in the Ebers papyrus from ancient Egypt [1, 7]. Circa 230 BC, Apollonius of Memphis first used the term 'diabetes'; however, its cause and the organ responsible for this condition were not elucidated until more than two millennia later (in the late nineteenth century) [1, 7].

In 1889, in the laboratory of Oscar Minkowski and Joseph von Mering, it was observed that a dog developed diabetes, with all of the characteristic symptoms of the disease, after total pancreatectomy [8]. This finally confirmed the central role of the pancreas in the etiopathogenesis of diabetes. Later in 1893, Eduoard Hédon further
Fig. 1 A timeline highlighting significant contributions to the development of insulin as a therapeutic agent for the treatment of diabetes and the development of modified insulins with prolonged times of action

\section{9}

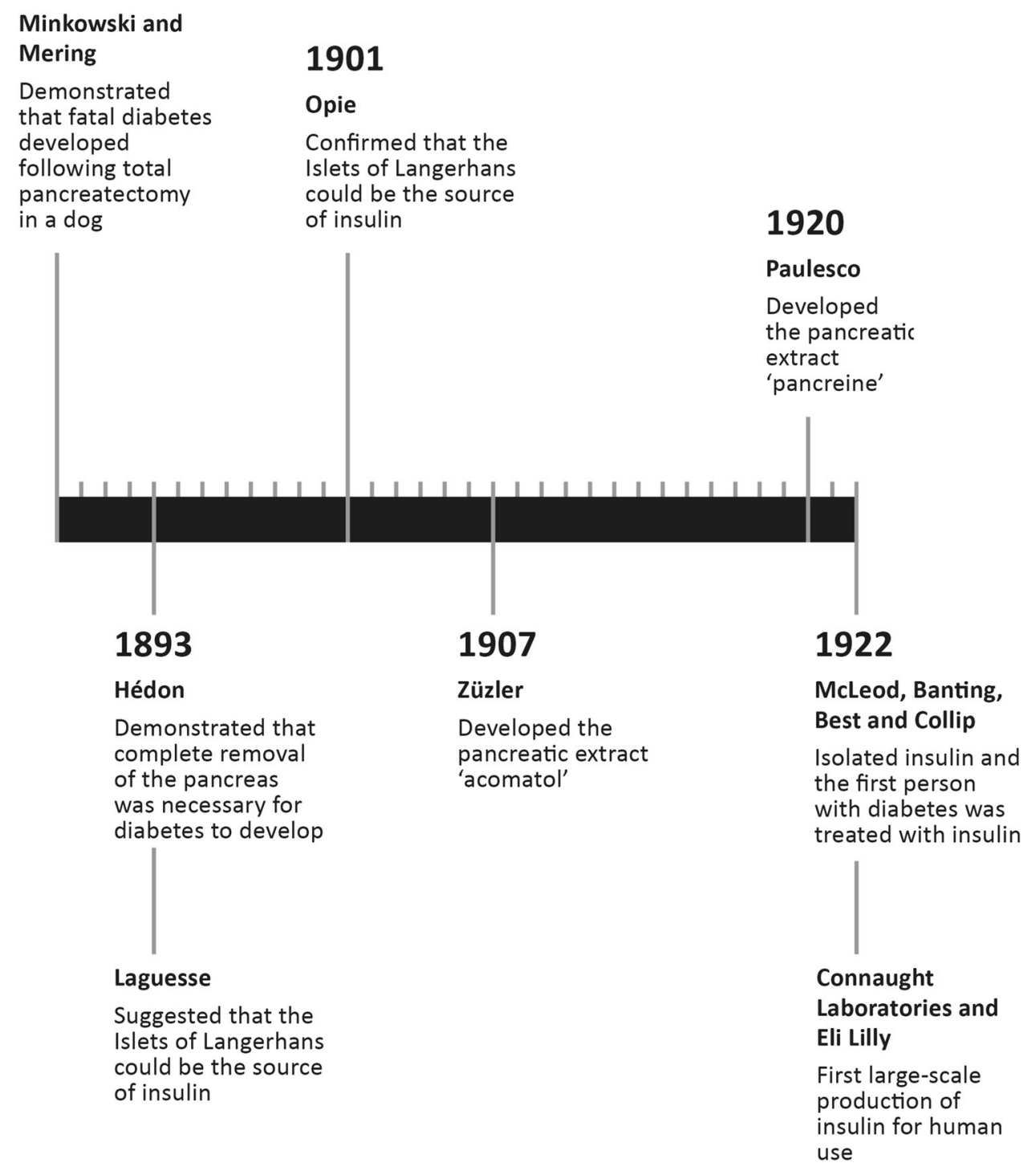


demonstrated that, in animals, complete removal of the pancreas was required for the development of diabetes [9]. Hédon observed that grafting a small piece of pancreatic tissue under the skin after total pancreatectomy alleviated diabetes, but it promptly returned on removal of the tissue. This was also demonstrated independently by Minkowski and, in 1893, led Gustave-Eduoard Laguesse to suggest that the small clusters of ductless cells within the pancreasthat had been described by Paul Langerhans in his doctoral thesis, and that he named the Islets of Langerhans-could be the source of the substance involved in glucose control $[5,10]$. This association between the islet cells and diabetes was confirmed in 1901 by Eugene Opie who connected the degeneration of the islet cells to the appearance of diabetes $[1,11,12]$. Subsequently, numerous attempts were made to isolate the glucose-lowering substance, with varying success, by a number of investigators, including Georg Ludwig Züzler (alcohol and saline extraction) [13], Nicolas Paulesco (ice-cold water) [14], Ernest Lyman Scott (acid and ethanol extraction) [15], Israel Kleiner and Samuel James Meltzer (water and saline dilution) [16], John Rennie and Thomas Fraser (boiling water and weak acetic acid) [17], and CP Kimball and John Murlin (acid and alcohol extraction) [18], among others [1, 5, 19, 20].

In 1907, Züzler removed the pancreas from a dog, extracted the pancreas with alcohol and injected the same dog with this extract, which he called 'acomatol'. He observed that it reduced the amount of glycosuria and raised the $\mathrm{pH}$ of the blood [1]. Soon after, in 1908, he used the extract to revive a subject who was in diabetic coma. However, the treatment produced severe complications, which were ascribed to toxic impurities in the extract. The person later died when the supply of the extract ran out; nevertheless, Züzler continued his attempts to produce a pure extract for a further few years and, in 1911, HoffmanLa Roche assisted Züzler's creation of an experimental laboratory [5, 13, 19, 21]. On 28 May 1912, acomatol was granted a patent (Patent 1027790) [21].

In 1916, Paulesco injected a diabetic dog with a pancreatic extract, extracted with ice-cold water, and observed that this led to the death of the dog from hypoglycemia, with its blood glucose levels falling from 140 to $26 \mathrm{mg} \%$ [1, 5, 14]. In 1921, Paulesco presented papers at meetings of the Romanian Society of Biology on his experiments in dogs (21 April, 19 May, and 23 June), and these results were published in France on 23 July 1921 [14, 21]. These demonstrated that his pancreatic extract, 'pancreine', reduced blood sugar, ketones, urea, and urine in both normal and depancreatized dogs [22-25]. Further details of this work were published in France on 31 August 1921 and, on 10 April 1922, he filed a patent application with the Romanian Government for pancreine [21, 23]. The publication of these results was delayed owing to the First
World War, and this also meant that there was a hiatus during which his research was effectively put on hold, delaying his progress. In 1919, Kleiner reported on his work, whereby he extracted freshly ground dog pancreas with salted distilled water; in all 16 reported experiments, the extract caused a temporary decrease in the blood sugar levels of depancreatized dogs [16, 20]. However, these decreases in blood sugar levels were accompanied by mild toxic symptoms-most commonly, elevated temperature.

\subsection{The Successful Extraction and Use of Insulin} to Treat Human Diabetes

On 17 May 1921, Banting and Best began working together in Professor JR Macleod's laboratory at the University of Toronto and, within 6 months, had succeeded in both extracting insulin and demonstrating that their crude extract reduced blood glucose in pancreatectomized dogs [26]. Over the course of the next 2 years (1921-1922), Frederick Banting, Charles Best, and John James Rickard Macleod, with the invaluable assistance of the chemist James Collip, achieved an improved extract of insulin from animal pancreata and successfully administered the extract to individuals with diabetes mellitus [26, 27]. Their original process involved ligating the pancreatic duct, therefore destroying the exocrine pancreas, and isolating the endocrine-producing islet of Langerhans from whole pancreas followed by acid-ethanol extraction [28]. This approach was adopted as Banting thought that this would yield a purer extract, free from trypsin, which would degrade the active principle. However, owing to the labor-intensive surgery needed to ligate the pancreas, production of the extract was slow and other approaches were attempted. Initially, they used secretin-exhausted glands for the extraction, which had been produced by slow injection of secretin over $4 \mathrm{~h}$ until the flow of pancreatic fluid through a cannula placed in the pancreatic duct stopped [20]. This was also extremely labor intensive and, on 6 December 1921, they extracted fetal-calf pancreas with slightly acidic $95 \%$ alcohol, and the extract successfully lowered blood glucose levels. Finally, on 11 December 1921, they performed the extraction on whole adult cow pancreas, and this extract reduced a depancreatized dog's blood sugar from 0.460 to $0.180 \%$ in $3 \mathrm{~h}[20,29]$. This discovery that insulin could be extracted from whole pancreas was a major step towards its successful use in treating diabetes, as the extract was available from a cheap and readily available source material.

Having demonstrated that their extract reduced blood glucose levels in dogs, they moved on to human trials. The first administration to a person with diabetes, 14-year-old Leonard Thompson, occurred in January 1922 [20, 27, 30]. This resulted in a reduction of blood sugar levels from 
0.440 to $0.320 \%$, as well as a drop in the 24 -h excretion of glucose from 91.5 to $84 \mathrm{~g}$ [20, 27]. However, no clinical benefit was observed and severe local reactions, including abscesses, were observed. This extract was described as a murky, light-brown liquid, and Collip subsequently provided an improved extract of greater purity, which was tested on 23 January 1922 on Leonard Thompson [20, 27]. Frequent injections over the first $24 \mathrm{~h}$ of treatment resulted in immediate improvement, with blood sugar levels dropping from 0.520 to 0.120 , and glucose excretion from 71.1 to $8.7 \mathrm{~g}$, and the elimination of ketonuria, accompanied by an associated symptomatic improvement [1, 20, 27, 30]. This purer and more consistent extract did not result in such severe injection-site reactions, highlighting the importance of obtaining as pure an extract as possible. Subsequently, the patent for the production of insulin was given to the University of Toronto by Banting, Best, and Collip.

The discovery of insulin represented a significant moment in medical history, with Banting and Macleod being awarded the 1923 Nobel Prize in Physiology or Medicine for the discovery of insulin. Banting shared his prize money with Best, and Macleod shared his with Collip; however, there is still controversy over the awarding of this Nobel Prize [20, 21]. The availability of insulin meant that people with insulin-requiring diabetes could now survive and successfully manage their disease.

\section{Large-Scale Production of Insulin}

The life-giving properties of insulin led to great demand worldwide, and therefore a need for improved production and purification techniques. Connaught Laboratories, a predecessor company of Sanofi, initiated large-scale production of insulin, which enabled additional but limited clinical testing [31]. However, there were difficulties in scaling up the production of insulin, including a period when they were unable to produce an extract with a similar potency to that originally investigated, as well as obtaining reduced yields. This reduced yield and potency was related to the use of heating to evaporate the alcohol following extraction, which destroyed some of the insulin present. By modifying this step to an evaporation technique involving a milder warm air current, insulin production could continue [20]. Nonetheless, Connaught Laboratories were unable to produce enough insulin to meet clinical demand and so they entered into collaboration with Eli Lilly to develop larger-scale production techniques; this enabled them to escalate production to meet global demand [1].

The insulin being produced at this time was inconsistent, with wide batch-to-batch variation in potency [20]. This meant that people being treated had to be closely monitored and, between October and December 1922, George Walden, Eli Lilly's chief chemist, developed a purification technique that enabled the production of insulin at a higher purity and with reduced batch-to-batch variation (10\% compared with $25 \%$ with the previous technique) [20]. He found that insulin precipitated from the extract under mildly acidic conditions. By adjusting the solution to insulin's isoelectric point, insulin of much greater purity could be obtained [20]. Another group, led by Phillip Shaffer, discovered the isoelectric precipitation method of purification at a similar time independently of Eli Lilly, which resulted in Eli Lilly Company accepting a non-exclusive licensing contract for the production of insulin from the University of Toronto. This important step meant that other companies could also produce insulin, enabling rapid, widespread, large-scale production of insulin [31]. By 1925, there were 12 different pharmaceutical companies producing insulin, which emphasized the enormous global demand that existed for insulin to treat diabetes [1].

\section{Development of Synthetic Human Insulin}

The first insulin preparations were porcine- and/or bovinebased. It was not until the 1980s that semi-synthetic human insulin became clinically available [32-34]. Human insulin had been available in small quantities since the 1960s; it was extracted from human cadaveric pancreases [1, 35-40] and was used as reference material in insulin radioimmunoassay or physicochemical identity tests [1, 41]. This human insulin was also used clinically in a limited manner for skin-testing of insulin-allergic individuals [42], pharmacokinetic studies [43-45], and short-term clinical studies $[1,46]$. Owing to the limited availability, efforts were undertaken to produce a synthetic version of human insulin in the belief that human insulin was preferable to animal insulin. The first total chemical synthesis of human insulin was performed in 1974 by Sieber and his co-workers [47], and this was shown to be biologically equivalent to the natural hormone [48]. However, this method comprised several hundred reactions and was too costly for widespread use. Therefore, alternative approaches for the synthesis of insulin were examined, with many groups focusing on the conversion of porcine to human insulin [1]. The first successful semi-synthesis was carried out by Obermeier and Geiger in 1976, but the overall yield was very low $(\sim 6$ to $10 \%)$ [49]. The breakthrough that enabled the large-scale production of human insulin was the discovery that the hydrolytic reaction normally performed by proteases could be reversed by carrying out the reaction in a mixture of water and organic solvent, thus enabling the formation of peptide bonds [50]. Several 
methods were developed involving enzymatic transformations, including the direct conversion of porcine insulin to human insulin ester via transpeptidation, as discussed by Markussen et al. [33]. This process produced the ester in a yield of $97 \%$ and this mixture was purified to meet the specifications of mono-component insulin $[1,33]$.

The introduction of recombinant DNA technology meant that, by the end of the 1980s, most human insulin was produced biosynthetically [17]. These recombinant insulins were produced using either Escherichia coli or yeast (Saccharomyces cerevisiae). In the first recombinant human insulins, the A and B chains were produced separately and then combined to produce insulin [28]. Subsequently, it has also been prepared by the biosynthetic production of human proinsulin, either within the expressing cell or excreted from it, which is then converted enzymatically to human insulin $[1,17,51]$.

\subsection{Insulin Modification}

The goal of exogenous insulin therapy is to mimic normal endogenous insulin secretion, which adapts to fasting and prandial conditions. When insulin therapy was first introduced for clinical use, it was available only as a short-acting formulation requiring multiple daily injections. This meant that, from the outset, there was a drive to develop new formulations of insulin and explore different routes of administration to make insulin treatment easier for people to manage and tolerate. Early attempts were made to administer insulin by alternative routes. Enteral administration met with very little success, as insulin is destroyed by enzymes in the stomach and small intestine, and there is no appreciable absorption from the large intestine [52]. However, this approach has seen resurgence, with several phase II trials of oral insulin therapy ongoing. Other routes of administration-such as inhalation-were also deemed to be unsuccessful due to poor bioavailability [52]. Consequently, attention was redirected to protracting the absorption of subcutaneously administered insulin in order to reduce the number of daily injections required. This led to the development of insulin preparations with prolonged effect, described as 'intermediate-' and 'long-acting' insulin formulations (Fig. 1) [53]. The pharmacokinetics of currently available insulin preparations are summarized in Table 1.

The early attempts at developing protracted forms of insulin therapy made use of additives such as gum arabic solutions, oil suspensions, and lecithin emulsions to delay subcutaneous absorption [52]. Attempts were also made to prolong the action of insulin by administering the insulin solution with a vasoconstrictor, such as pituitrin or epinephrine; however, all of these met with little success [52]. The next generation involved combining neutral suspensions of insulin with zinc ions and/or highly basic proteins such as protamines [52, 54]. In the 1930s, globin and surfen
Table 1 Pharmacokinetics of currently available insulin preparations [130]

\begin{tabular}{llll}
\hline Insulin preparations & Onset (h) & $\begin{array}{l}\text { Peak } \\
(\mathrm{h})\end{array}$ & $\begin{array}{l}\text { Duration } \\
(\mathrm{h})\end{array}$ \\
\hline $\begin{array}{l}\text { Rapid-acting } \\
\quad \text { Regular }\end{array}$ & $0.5-1$ & $2.5-5$ & $8-12$ \\
$\quad$ Insulin lispro (Humalog) & $0.25-0.5$ & $0.5-1.5$ & $2-5$ \\
$\quad$ Insulin aspart (NovoLog) & $0.17-0.33$ & $1-3$ & $3-5$ \\
$\quad$ Insulin glulisine (Apidra) & 0.25 & $0.5-1.5$ & $1-2.5$ \\
Intermediate-acting & & & \\
$\quad$ NPH & $1-1.5$ & $6-14$ & $16-24$ \\
Long-acting & & & \\
$\quad$ Insulin glargine (Lantus) & 1.1 & - & 24 \\
$\quad$ Insulin detemir (Levemir) & $0.8-2$ & - & $\mathrm{Up}$ to 24 \\
Insulin degludec (Tresiba) & - & - & $>25$ \\
Premixed human & & & \\
$\quad$ NPH/R 70/30 & $0.5-1$ & $2-12$ & 24 \\
NPH/R 50/50 & $0.5-1$ & $2-12$ & 24 \\
Premixed analog & & & \\
Insulin protamine aspart/aspart & 0.25 & $1-3$ & 24 \\
$70 / 30$ (NovoLog mix) & & & \\
Insulin protamine lispro/lispro & 0.25 & $0.5-1.5$ & 24 \\
$75 / 25$ (Humalog mix) & & & \\
\hline
\end{tabular}

$N P H$ neutral protamine Hagedorn, $R$ regular

insulin were developed as potential prolonged-effect insulin preparations, the latter being formulated using a synthetic urea as an alternative to protamine [54-57]. At a similar time, protamine zinc insulin was developed [54, 58, 59]. This was a preparation of insulin with excess protamine and a small amount of zinc, which prolonged the hypoglycemic effect of the insulin beyond $24 \mathrm{~h}[54,58]$. Despite this protracted period of action, the use of protamine zinc insulin was limited by a greater risk of hypoglycemia, as well as a slow onset of action, which necessitated the addition of soluble insulin for immediate action [54, 60-62]. Unfortunately, the admixture of protamine zinc insulin and soluble insulin was unstable and the two types of insulin had to be given as two separate injections [63]. In 1946, neutral protamine Hagedorn (NPH) insulin, an intermediate-acting insulin developed by Hans Christian Hagedorn, became available [64]. This is a stable 'protamine zinc insulin' modification that combines insulin and protamine in 'isophane' proportions (i.e. no excess of insulin or protamine) at neutral $\mathrm{pH}$ in the presence of a small amount of zinc and phenol or phenol derivatives [65]. This insulin preparation has continued to be used as a 'basal' insulin up to the present time, recommended as a once- or twice-daily insulin, used either alone or in combination with a soluble insulin, as required. The timeline for the development of long-acting insulin preparations is shown in Fig. 2. 


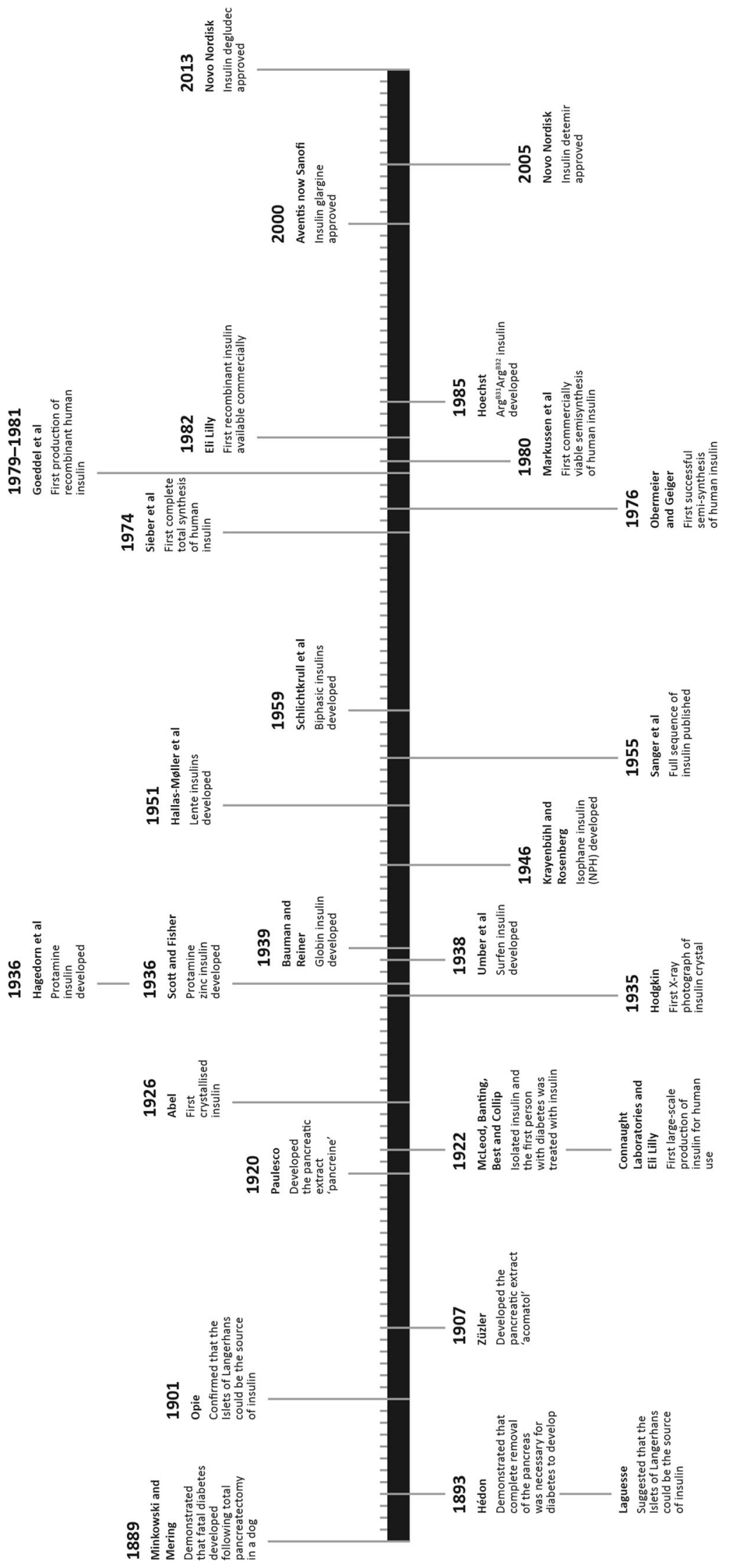


Early protracted animal insulins developed by HallasMøller and Schlichtkrull capitalized on the varying solubilities of their components (i.e. porcine and/or bovine insulins) at physiological $\mathrm{pH}$. The lente family of insulins (semilente, lente, and ultralente) were created by complexing neutral insulin suspensions with small amounts of zinc ions, in the absence of any added foreign proteins or synthetic compounds $[54,66]$. This provided a spectrum of time-action characteristics. The original lente insulin, which had an intermediate timing of action similar to that of NPH insulin, comprised a 30:70 mixture of amorphous porcine insulin and crystalline bovine insulin particles $[67,68]$. Bovine ultralente insulin formed fairly large crystals $(30 \mu \mathrm{m})$ that remained in a subcutaneous depot for a number of days, resulting in a duration of action similar to that of protamine zinc insulin, enabling once-daily administration [54].

The remainder of this review discusses insulin analog preparations that are designed to possess a protracted action, with a focus on insulin glargine, which was the first 'long-acting' insulin and was approved for clinical use in 2000.

\subsection{Long-Acting Insulin Preparations: Mimicking Basal Insulin Physiology}

The main role of basal insulin secretion is to limit hepatic glucose production and lipolysis in the fasting state, particularly overnight, without impairing glucose availability for brain function [69]. However, older basal insulin preparations, e.g. NPH and lente insulins, are acknowledged to be associated with a number of limitations, such as variable absorption with notable inter- and intra-individual variation, and discernible peak plasma concentrations after subcutaneous injection, thus increasing the risk of hypoglycemia (in particular, nocturnal hypoglycemia). Therefore, individuals treated with NPH insulin before the evening meal or before bed may be at an increased risk of fasting hyperglycemia. In addition, due its activity of less than $24 \mathrm{~h}$ duration, a second dose in the morning is often required. For example, even the longest-acting preparation, human ultralente, with a peak insulin level at $10-14 \mathrm{~h}$ postinjection, did not always provide adequate basal coverage with once-daily administration at the lower dose levels [51, 58].

Therefore, in an attempt to avoid the shortcomings of conventional basal insulin therapies, long-acting basal insulin analogs were developed. To date, there have been two main protraction strategies used: (1) modification of the insulin molecule to achieve a low solubility at physiological pH, e.g. insulin glargine; (2) the addition of a fatty-acid chain of variable length to the insulin molecule, which can bind to albumin, forming a circulating depot from which the insulin analog is slowly released, e.g. the insulins detemir and degludec. More recently, a third strategy is being explored that involves the pegylation of insulin, e.g. LY2605541 (insulin peglispro), which is currently undergoing extensive clinical evaluation [70, 71].

\subsection{Early Analogs: Modified Chemical Structures}

The elucidation of the chemical structure of animal insulin by Frederick Sanger and his group [72, 73] and, subsequently, human insulin by Nicol and Smith [35], and the determination of its three-dimensional structure by means of X-ray crystallography by Dorothy Hodgkin and colleagues [74], as well as by the Chinese Insulin Group, helped to reveal the relationship between proinsulin and insulin and the spatial arrangement of the insulin molecules within the hexamers (Fig. 3). These discoveries paved the way for the synthesis of insulin and the eventual development of new forms of rapid- and protracted-acting insulin preparations based on alterations to the structure of the insulin molecule itself (insulin analogs).

The human insulin molecule is a polypeptide with a molecular mass of 5,808 Daltons, comprising an A and a B chain connected by two disulphide bridges (Fig. 4a). By changing the amino-acid sequence in such a way that it does not prevent the interaction with either the insulin receptor or insulin-like growth-factor receptor (i.e. protein engineering), the 'absorption kinetics' of the insulin molecule can be altered [75]. This process has been widely and successfully used in the creation of short-acting analogs, working on the principle that hexamer stability in the subcutaneous depot could be decreased by alterations to structure or charge, leading to an increased dissociation rate of the hexamers into dimers and monomers at the site of injection, thereby enhancing the absorption of insulin into the systemic circulation [76].

During the 1980s, initial attempts at creating long-acting insulin analogs involved the addition of positive charges to the insulin molecule, either by removing carboxylates (Glu, Asp), or by the introduction of lysine or arginine using single-chain insulin precursors [54, 77-80]. Early efforts by Novo Nordisk involved changing $\mathrm{Glu}^{\mathrm{B} 27}$ to arginine and replacing the terminal carboxylate of the $\mathrm{B}$ chain by an amide $\left(\mathrm{Thr}^{\mathrm{B} 30}-\mathrm{NH}_{2}\right)$ [77-79]; further structural modifications created NovoSol Basal, a Gly ${ }^{\mathrm{A} 21} \mathrm{Arg}^{\mathrm{B} 27} \mathrm{Thr}^{\mathrm{B} 30}$ insulin amide [81]. Although NovoSol Basal achieved prolonged absorption compared with ultralente, it required double the dose for comparable glycemic control. NovoSol Basal also had low intra-individual variability, but high inter-individual variability. This agent failed in clinical testing in 1989, and this was thought to be due to subcutaneous crystal formation and degradation of the drug in the subcutaneous depot by significant macrophage infiltration, leading to reduced bioavailability [75]. 
Fig. 3 The three-dimensional structures of proinsulin (a), human insulin monomer (b), dimer (c), and hexamer (d). In b-d: green, A chain(s); magenta: B chain(s). In a, the C-peptide within proinsulin is indicated in blue. a Adapted from Yang et al. [128]; $\mathbf{b}, \mathbf{c}$ and d Adapted from Smith et al. [129]
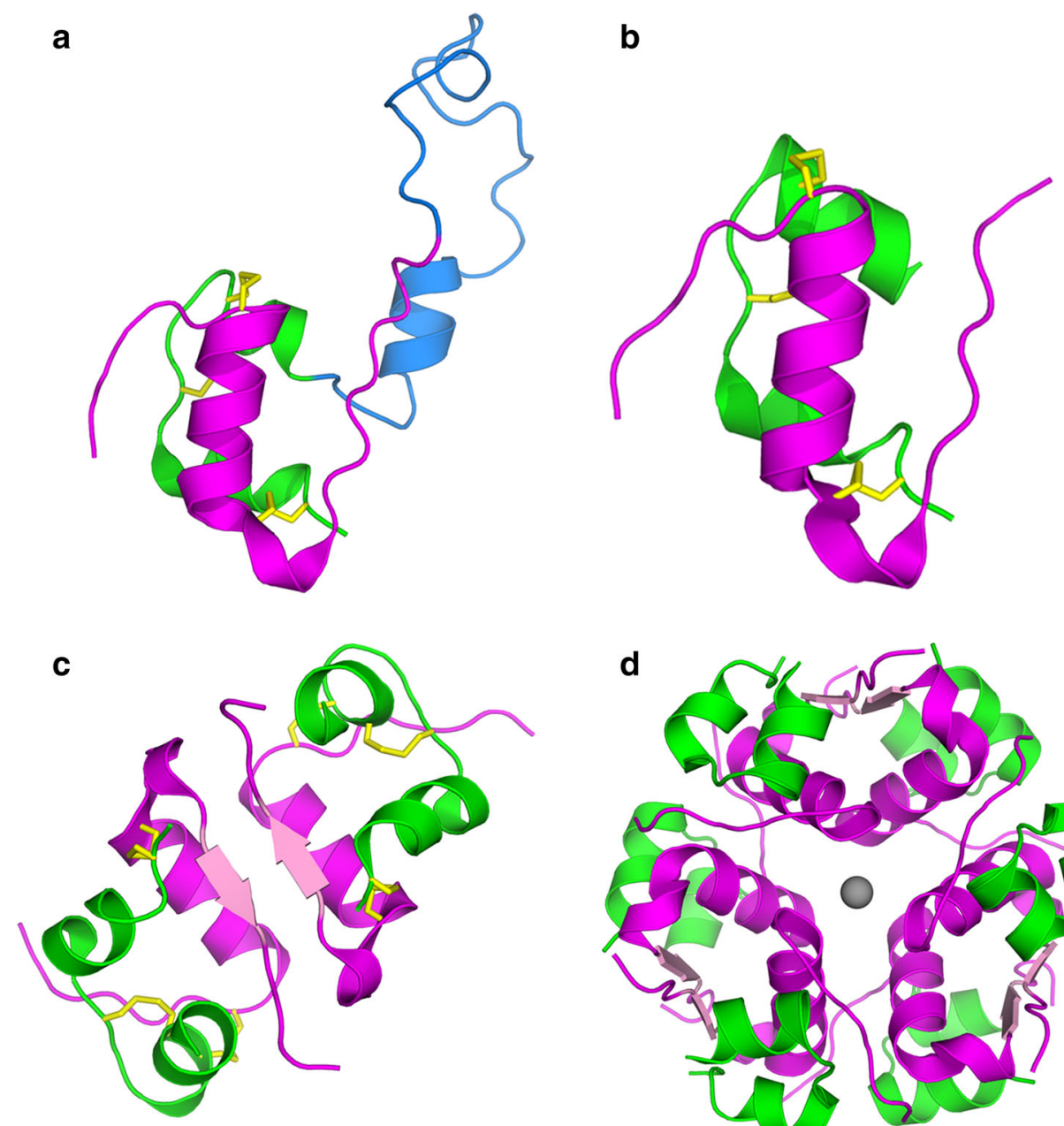

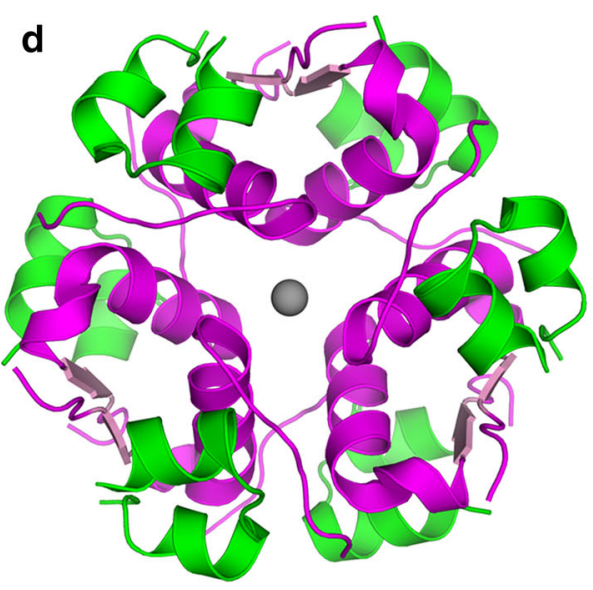

A di-arginine $\left(\mathrm{Arg}^{\mathrm{B} 31} \mathrm{Arg}^{\mathrm{B} 32}\right.$ ) preparation (Fig. $\left.4 \mathrm{~b}\right)[82$, 83] was obtained by trypsin cleavage of the biosynthetic precursor, proinsulin $[84,85]$. As these two arginines are present in proinsulin, linking the $\mathrm{B}$ chain to $\mathrm{C}$ peptide, and are cleaved off during its metabolism, retaining them was seen as a logical approach to the development of a longacting insulin [86]. Patents on this structural innovation were filed in 1983 and 1984 by Hoechst AG, a predecessor company of Sanofi. Initially, the simple concept behind these structural modifications was that they would cause a shift in the isoelectric point of the insulin analog from 5.4 towards a neutral $\mathrm{pH}$, consequently lowering solubility at physiological $\mathrm{pH}$. The injection of such a preparation would then result in amorphous precipitation and possibly crystallization in the subcutaneous tissue, leading to delayed absorption into the circulation [75]. Early results confirmed the efficacy of $\mathrm{Arg}^{\mathrm{B} 31} \mathrm{Arg}^{\mathrm{B} 32}$ insulin in rabbit models; although, in canine models after subcutaneous injection, this effect did not show any benefit over NPH insulin (Fig. 5a) and, consequently, development of this formulation was discontinued.
Subsequent investigation, in animal models, of subcutaneous injection of acidic solutions with varying zinc concentrations revealed that the lowest total potency of $20 \mu \mathrm{g} / \mathrm{mL}$ was the ideal concentration for $\operatorname{Arg}^{\mathrm{B} 31} \mathrm{Arg}^{\mathrm{B} 32}$ insulin crystallization in vitro, and may indicate a change in the morphology of the subcutaneous precipitate from amorphous to crystalline (Fig. 5b).

Findings from studies of long-acting insulin analogs demonstrate that, even in cases such as NovoSol Basal and $\operatorname{Arg}^{\mathrm{B} 31} \mathrm{Arg}^{\mathrm{B} 32}$ insulin, which have similar solubility profiles, variations in chemical structure can produce markedly different pharmacokinetic profiles and pharmacodynamic outcomes in vivo. This is highlighted by a study of NovoSol Basal in dogs, which reported lower total blood glucose-lowering properties than for insulin glargine (Fig. 5c). In addition, the failure of analogs such as $\mathrm{Arg}^{\mathrm{B}}$ to exhibit prolonged glucose-lowering activity in spite of an increased isoelectric point suggested that merely increasing the isoelectric point was too simple a concept to achieve prolonged activity; rather, the impact of the threedimensional structure seemed to play a major role. 

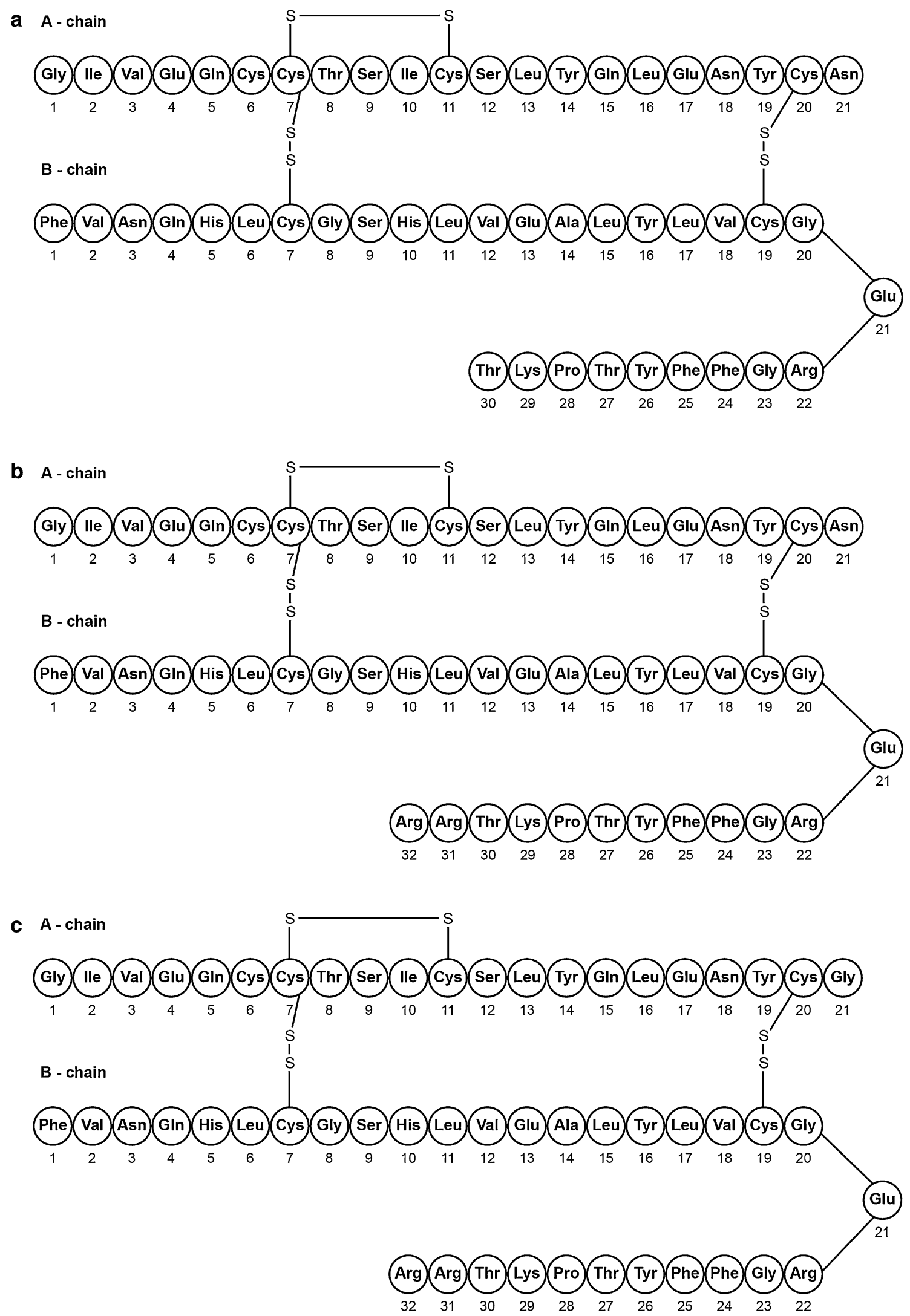

Fig. 4 Schematic structures of human insulin and insulin analogs (a), $\operatorname{Arg}^{\mathrm{B} 31} \mathrm{Arg}^{\mathrm{B} 32}$ insulin analog (b), and insulin glargine $\left(\mathrm{Gly}^{\mathrm{A} 21} \mathrm{Arg}^{\mathrm{B} 31} \mathrm{Arg}^{\mathrm{B} 32}\right)(\mathbf{c})$ 


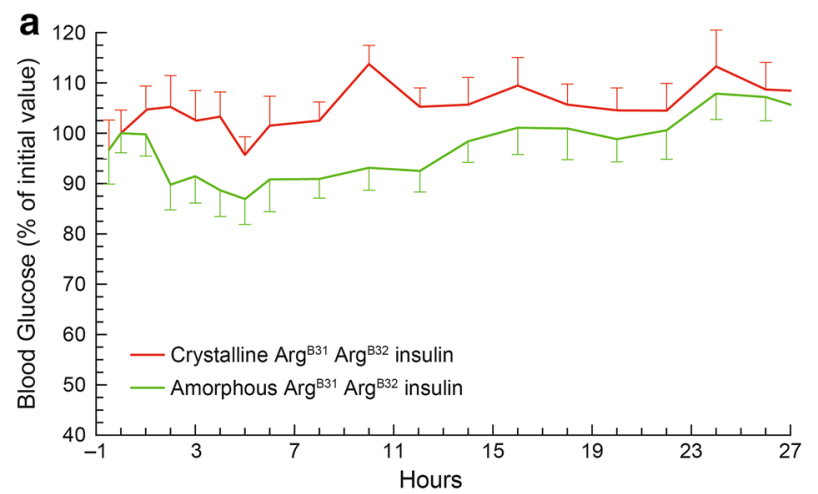

b
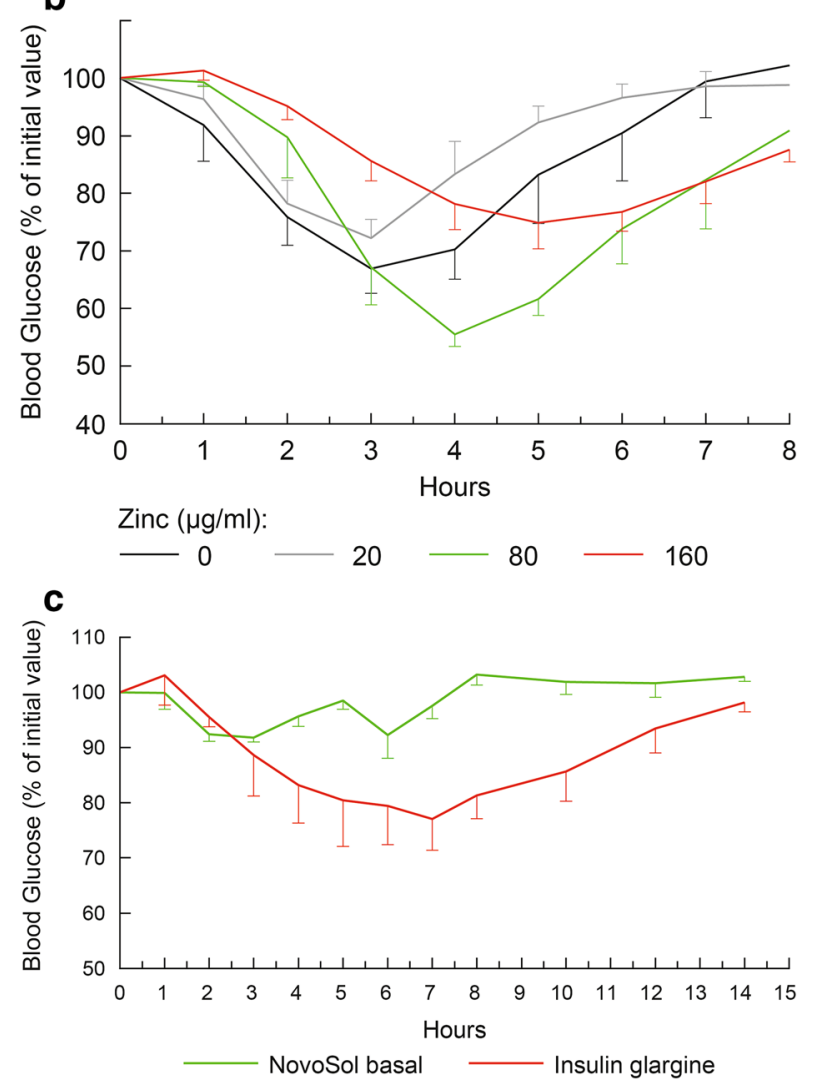

Fig. 5 (a) Blood glucose profiles after subcutaneous injection of either crystalline or amorphous $\mathrm{Arg}^{\mathrm{B} 31} \mathrm{Arg}^{\mathrm{B} 32}$ insulin $(0.3 \mathrm{IE} / \mathrm{kg})$ in $\operatorname{dogs}(n=6)$; (b) Blood-glucose profiles with $\mathrm{Arg}^{\mathrm{B} 31} \mathrm{Arg}^{\mathrm{B} 32}$ insulin $(0.3 \mathrm{IU} / \mathrm{kg})$ in dogs $(n=6)$ according to varying zinc concentrations; (c) Variations in blood-glucose profiles between NovoSol Basal and insulin glargine ( $\mathrm{pH} 4$ and $80 \mu \mathrm{g} / \mathrm{ml}$ zinc; $0.3 \mathrm{IU} / \mathrm{kg})$ in dogs $(n=6)$

It was at this point that structural biologists entered the stage. Initially, attention was focused on the role of phenol in stabilization (dimer-to-dimer interaction) of the insulin hexamer and monoclinic insulin crystals [87, 88]. Phenol or its derivatives were introduced as a bacteriostatic agent and preservative in insulin preparations; however, it was subsequently realized that phenol was critical in stabilizing the dimer-dimer interactions within the hexamer, thereby protracting the action of insulin [76, 88, 89]. Subsequent crystallographic analyses of the long-acting insulins focused on the contact areas between insulin hexamers in phenol-containing monoclinic crystals. It could be shown that the addition of extra arginine residues at the C-terminal of the B-chain leads to an increase in the number of polar interactions between hexamers in the crystals, concomitant with a higher packing density of the crystals and a reduced water content. Thus, phenol-containing, monoclinic crystals of human insulin comprise $49.8 \%$ solvent (Fig. 6a). Attachment of two arginine residues at the C-terminus of the $\mathrm{B}$ chain, as in $\mathrm{Arg}^{\mathrm{B} 31} \mathrm{Arg}^{\mathrm{B} 32}$ insulin, introduces many additional hydrogen-bonding and saltbridge interactions between neighboring hexamers, leading to a shrinkage of the unit cell of the monoclinic crystals with a lower water content ( $43 \%)$, and a higher packing density (Table 2; Fig. 6b). The addition of a single arginine residue at the $\mathrm{C}$-terminus of the $\mathrm{B}$ chain $\left(\mathrm{Arg}^{\mathrm{B} 31}\right.$ insulin) resulted in a water content and packing density between that seen with human insulin and $\operatorname{Arg}^{\mathrm{B} 31} \mathrm{Arg}^{\mathrm{B} 32}$ insulin (Table 2; Fig. 6c). The activity of $\mathrm{Arg}^{\mathrm{B} 31}$ insulin is protracted by about $2 \mathrm{~h}$ compared with human insulin. A correlation between crystal packing density and duration of activity was observed, suggesting that stable crystal formation at physiological $\mathrm{pH}$ was important for the protraction of time-action. In the case of $\mathrm{Arg}^{\mathrm{B} 31} \mathrm{Arg}^{\mathrm{B} 32}$ insulin, pre-formed crystals with their tight packing are subject to very slow solubilization following subcutaneous injection, and this may ultimately explain the loss of activity following injection of solutions with high crystallization tendencies. Thus, although low solubility at physiological $\mathrm{pH}$ is necessary for prolonged duration of insulin action, it is not sufficient alone: attention must also be paid to the degree of inter-hexamer interaction and crystal stability against dissolution. It is also of interest that even uncharged residues that are capable of making extra interactions and/or reducing the solubility of the insulin derivative (such as phenylalanine in both positions B31 and B32) were found to lead to a prolonged activity profile; thus, the effect did not only depend on a shift of the isoelectric point. Even in the case of $\mathrm{Phe}^{\mathrm{B} 31} \mathrm{Phe}^{\mathrm{B} 32}$ insulin, the correlation between reduced water content of the crystals (46.9\%) and the duration of activity was found to hold true.

\section{Development of Insulin Glargine (Lantus ${ }^{\circledR}$ )}

Subsequent steps were taken by Hoechst AG to improve on the structure of the $\mathrm{Arg}^{\mathrm{B} 31} \mathrm{Arg}^{\mathrm{B} 32}$ insulin analog to maintain a low solubility at physiological $\mathrm{pH}$ in order to achieve a more prolonged bioavailability, and many analogs were made that contained a range of different modifications [90, 91]. X-ray crystallographic data indicated that position A21 
Fig. 6 The channel between four neighboring hexamers in the crystal structures of human insulin (a), $\operatorname{Arg}^{\mathrm{B} 31} \mathrm{Arg}^{\mathrm{B} 32}$ insulin (b), $\operatorname{Arg}^{\mathrm{B} 31}$ insulin (c), and insulin glargine (d); crystal structure highlighting the packing of a monoclinic insulin crystal (e); and threedimensional structure of the insulin glargine hexamer (f)
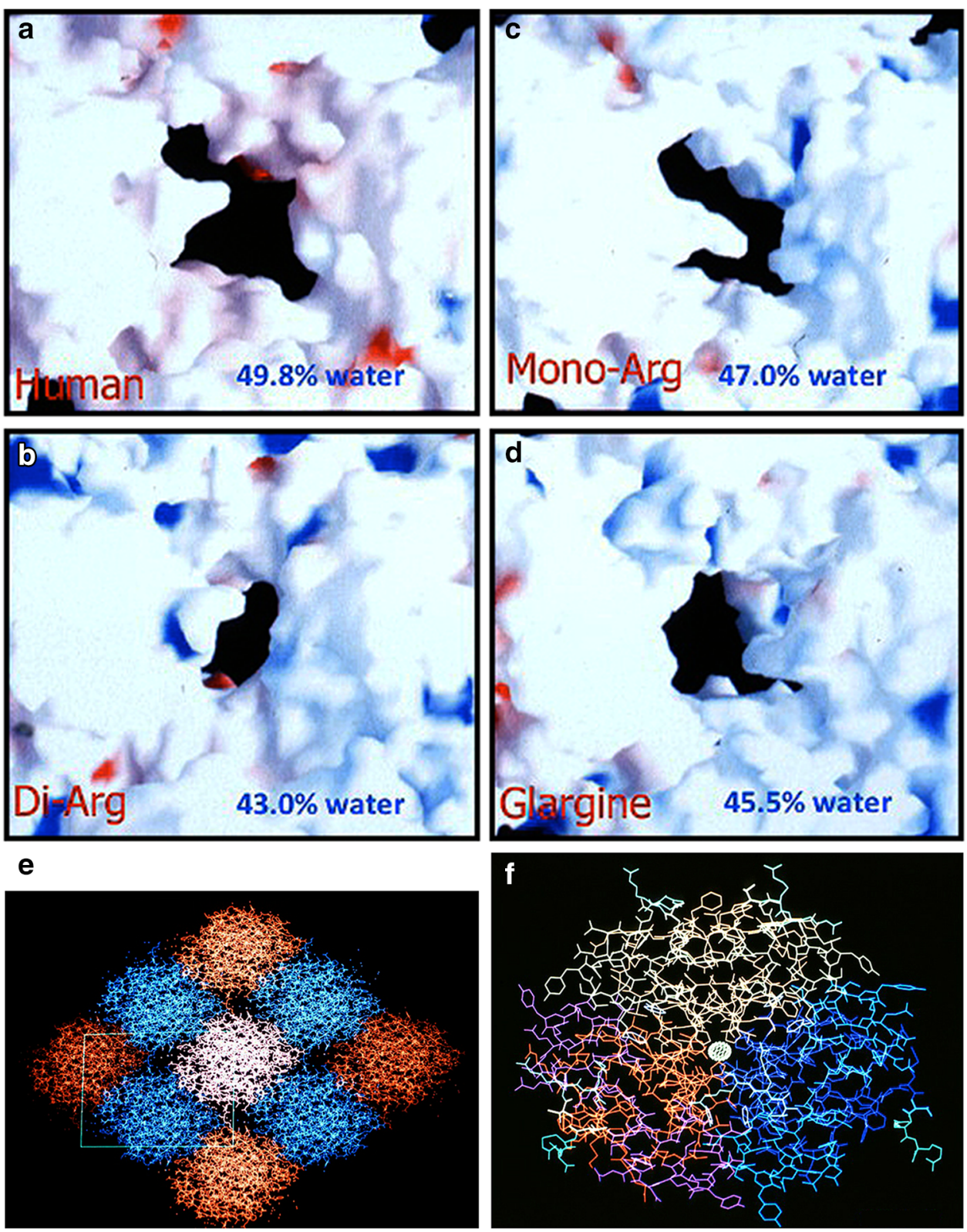

of the $\mathrm{Arg}^{\mathrm{B} 31} \mathrm{Arg}^{\mathrm{B} 32}$ insulin structure was involved in several inter-hexamer contacts, thereby stabilizing higher aggregates, with substitution of this position having the potential to destabilize these interactions. Minor modification of $\mathrm{Arg}^{\mathrm{B} 31} \mathrm{Arg}^{\mathrm{B} 32}$ insulin by the replacement of asparagine at $\mathrm{A} 21$ with glycine $\left(\mathrm{Gly}^{\mathrm{A} 21}\right)$ resulted in a less dense crystal packing and a somewhat higher water content $(45.5 \%)$, as well as a reduction in the number of interhexamer interactions (Table 2; Fig. 6d) [92]. In addition, this modification created space for the binding of a seventh phenol molecule at the periphery of the insulin hexamer, in addition to the six phenols located at the center of the hexamer, near $\mathrm{His}^{\mathrm{B} 5}$ and $\mathrm{Cys}^{\mathrm{A} 6}$ as well as $\mathrm{Cys}^{\mathrm{A} 11}$ [87]. Combination of these structural elements-Gly ${ }^{\mathrm{A} 21}$ and
$\operatorname{Arg}^{\mathrm{B} 31} \mathrm{Arg}^{\mathrm{B} 32}$ — achieved a more prolonged blood glucoselowering action in animal models (Fig. 7). Zinc dependency was limited to a small concentration range $(0-20 \mu \mathrm{g} /$ $\mathrm{mL}$ ) and was not correlated with any loss of glucoselowering activity. Clinical studies were performed comparing NPH insulin with insulin glargine containing either 30 or $80 \mu \mathrm{g} / \mathrm{mL}$ [93-95]. In these studies, no clinical difference was observed with the different zinc concentrations and so insulin glargine containing $30 \mu \mathrm{g} / \mathrm{mL}$ zinc was selected for use in the final product formulation, as it offered good stability with the lowest suitable zinc concentration [94]. Figure 6e, f illustrates the crystal structure of insulin glargine, highlighting the three dimers, phenol molecules, and zinc ions. 
Table 2 Packing density and inter-hexamer contacts in monoclinic crystals of insulin and insulin analogs

\begin{tabular}{lllll}
\hline Insulin & $\begin{array}{l}\text { Crystal } \\
\text { packing } \\
\text { density } \\
\left(\mathrm{Da} / \AA^{3}\right)\end{array}$ & $\begin{array}{l}\text { Water } \\
\text { content } \\
(\%)\end{array}$ & $\begin{array}{l}\text { Hydrogen } \\
\text { bonds }(n)\end{array}$ & $\begin{array}{l}\text { Salt } \\
\text { bridges } \\
(n)\end{array}$ \\
\hline Human insulin & 0.40 & 50 & 15 & 5 \\
$\mathrm{Arg}^{\mathrm{B} 31}$ & 0.43 & 47 & n.d. & n.d. \\
$\mathrm{Arg}^{\mathrm{B} 31} \mathrm{Arg}^{\mathrm{B} 32}$ & 0.46 & 43 & 24 & 6 \\
$\begin{array}{c}\mathrm{Gly}^{\mathrm{A} 21} \mathrm{Arg}^{\mathrm{B} 31} \mathrm{Arg}^{\mathrm{B} 32} \\
(\text { Insulin glargine) }\end{array}$ & 0.44 & 45.5 & 18 & 4 \\
\hline
\end{tabular}

The packing density is given as molecular mass of the protein (in Dalton) divided by the volume of the asymmetric unit of the crystal that contains this protein (in $\AA^{3}$ ). Water or additives are not included in this parameter. A higher packing density correlates with more interactions between the protein molecules and with a lower water content

n.d. Not determined
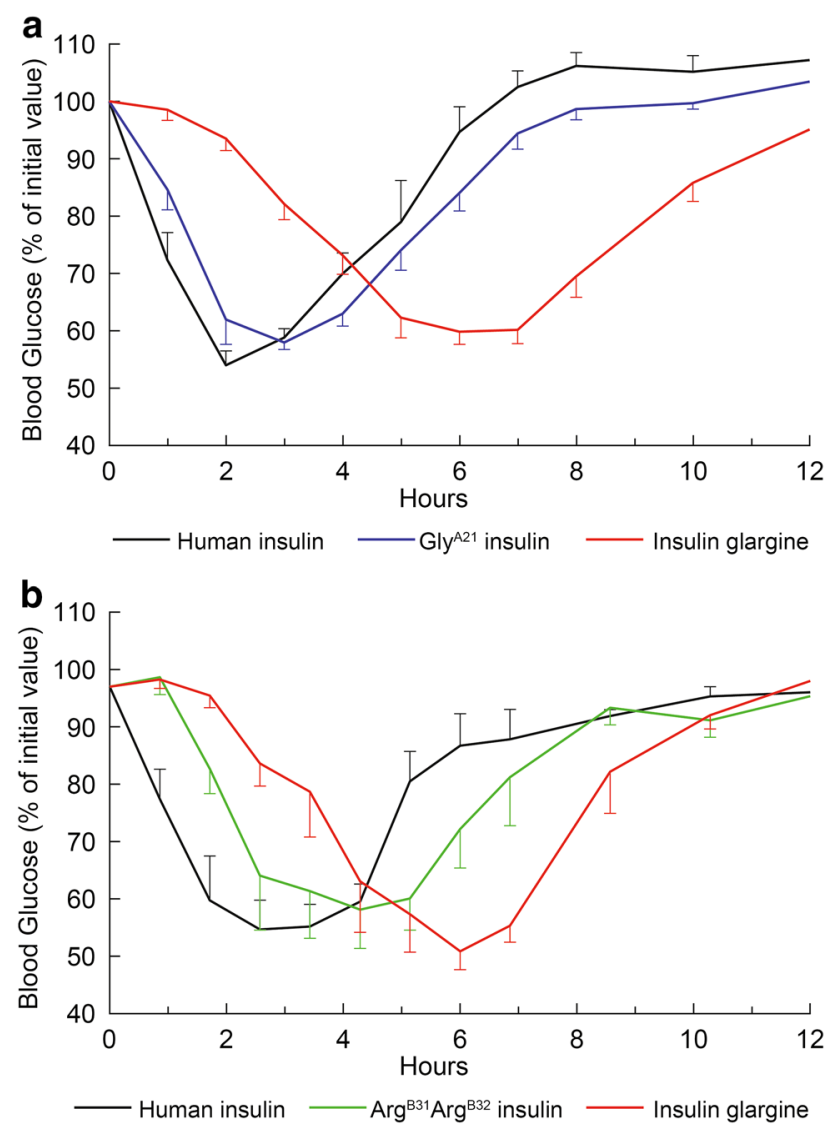

Fig. 7 The contributions of both $\mathrm{Gly}^{\mathrm{A} 21}$ (a) and $\mathrm{Arg}^{\mathrm{B} 31} \mathrm{Arg}^{\mathrm{B} 32}$ (b) modifications to the overall glucose-lowering effects of insulin glargine ( $\mathrm{pH} 4,40 \mathrm{IU} / \mathrm{ml}, 80 \mu \mathrm{g} / \mathrm{ml}$ zinc, $\operatorname{dogs}[n=6], 0.3 \mathrm{IU} / \mathrm{kg}$ s.c.)

As a result of its chemical structure, this insulin analog is less soluble at neutral $\mathrm{pH}$ than human insulin and precipitates in the subcutaneous tissue post-injection, slowing its absorption and extending its duration of action [87]. The structural properties of insulin glargine mean that it is soluble in acidic solutions ( $\mathrm{pH} 4$ ) and does not require resuspension prior to injection, unlike NPH insulin. This need for resuspension was the predominant cause of the increased variability in the time-action characteristics of NPH insulin [96]. Furthermore, insulin glargine functions essentially as a 'prodrug' in the subcutaneous tissue, with the majority of activity from its metabolites.

Following subcutaneous injection, insulin glargine is rapidly metabolized into its two main active metabolites: M1 (Gly ${ }^{\mathrm{A} 21}$ ) and M2 (Gly ${ }^{\mathrm{A} 21}$, des-Thr $\left.{ }^{\mathrm{B} 30}\right)$ [97], with little or no glargine molecule being detected in the systemic circulation. The M1 metabolite accounts for approximately $90 \%$ of the available daily plasma insulin [97], and its release from the poorly soluble parent compound is the primary mechanism, resulting in the pharmacokinetic characteristics and consequent pharmacodynamic effect with the long-acting time-action profile observed with insulin glargine treatment [98-100]. Steady state is attained within a few days [101]. Importantly, adverse events, injection-site reactions, and antibody formation with insulin glargine were found to be comparable with NPH [75].

A patent for the $\mathrm{Gly}^{\mathrm{A} 21} \mathrm{Arg}^{\mathrm{B} 31} \mathrm{Arg}^{\mathrm{B} 32}$ insulin analog, i.e. insulin glargine (Fig. 4c), was filed in 1988, and a New Drug Application was made in the USA and Europe in April 1999. Following an extensive clinical trial program, insulin glargine was approved by the US FDA and the European Medicines Agency for once-daily subcutaneous administration for the treatment of type 1 diabetes mellitus (T1DM) and T2DM in the year 2000.

\section{Clinical Experience with Insulin Glargine}

The recent joint recommendations from the American Diabetes Association (ADA) and the European Association for the Study of Diabetes (EASD) highlight the importance of basal insulin therapy in people with T2DM. These guidelines recommend the individualization of care and the progressive intensification of therapy until glycemic targets (glycated hemoglobin $\left[\mathrm{HbA}_{1 \mathrm{c}}\right]<7.0 \%$ ) are met [102]. NPH insulin is still an effective and valuable intermediateacting insulin. However, the clinical need for an effective long-acting agent to reduce the number of injections required and lower the risk of hypoglycemia, whilst striving to achieve near normoglycemia led to the rapid adoption of long-acting insulin analogs.

Clinical studies have demonstrated that, compared with $\mathrm{NPH}$, glargine has a more prolonged duration of action of up to $24 \mathrm{~h}$ due to a slower and more delayed absorption from the subcutaneous tissue, reduced variability, and a relatively consistent, peakless concentration-time profile, thus reducing the risk of hypoglycemia [58, 103-105]. 
Glargine was the first once-daily, long-acting insulin ana$\log$ to be introduced into clinical practice, and it has now been in clinical use for more than 10 years [54].

It has been suggested that insulin analogs may be associated with an increased risk of cancer compared with human insulin, owing to enhanced affinities for the insulin receptor or the insulin-like growth factor receptor [97]. However, the di-arginyl molecules in insulin glargine, which increase binding to the insulin-like growth factor receptor in vitro, are not present in the glargine M1 metabolite, and the metabolic and mitogenic characteristics of both the M1 and M2 metabolites have been shown to be essentially similar to those of human insulin [97, 106]. Indeed, large epidemiological studies indicate that insulin glargine does not have any independent carcinogenic effects at therapeutic doses [107-109]. This is strongly supported by the ORIGIN (Outcome Reduction with Initial Glargine INtervention) study of 12,537 people with early T2DM or pre-diabetes, which included cancer incidence as a secondary outcome [110]. This represents the longest randomized controlled study of insulin therapy, extending over a median period of 6.2 years, with no increase seen in the incidence of all cancers combined, any organ-specific cancer (including breast, lung, colon, prostate, and melanoma), or cancer in the glargine group compared with the standard care group.

In people with T1DM, glargine offers improved convenience, with only once-daily administration, and flexibility as to timing of injection (morning, pre-dinner, or prebedtime) [111]. In people with T2DM, glargine offers both increased safety (reduced risk of nocturnal hypoglycemia) and convenience (once-daily administration) when attempting to reach the target $\mathrm{HbA}_{1 \mathrm{c}}$ level of $7.0 \%$ and below, which is achieved in more than $50 \%$ of subjects [112].

The efficacy and safety of insulin glargine in both people with T1DM and those with T2DM have been demonstrated in a number of key randomized controlled clinical studies. An overview of some of the key trials is presented in Supplementary Table 1. Importantly, insulin glargine can be used successfully with other oral and parenteral agents in the treatment of T2DM; for example, in combination with prandial insulin or prandial glucagonlike peptide (GLP)-1 receptor agonists as part of a basalbolus therapy $[54,113,114]$. This offers a new option for the intensification of treatment of people with T2DM who are not reaching glycemic targets despite receiving basal insulin therapy. Currently, treatment is usually intensified by the addition of prandial insulin, either as premixed insulin or as separate injections. However, this increases the risk of hypoglycemia and weight gain, side effects not observed with GLP-1 receptor agonists, which have a low risk of hypoglycemia and either a neutral effect on weight or cause weight loss [115-118].

Insulin analogs tend to be associated with higher initial medication costs than NPH and for this reason there is debate as to whether they offer value for money in clinical practice [119]. Cost-effectiveness analyses have demonstrated that the initial expenditure associated with insulin analogs is offset by reductions in the incidences of hypoglycemia associated with their use [120-122]. Other studies indicate that there may be no such cost reductions [123]. While cost may be a consideration, it is only one of several important factors that need to be considered when deciding the most appropriate treatment regimen for patients with diabetes. Blood glucose control, tolerability, adverse events, patient adherence to treatment, and quality of life are all essential considerations. Lower incidences of nocturnal and severe hypoglycemia [124] and improvements in patient adherence and quality of life have been reported with use of insulin analogs due to the need for fewer injections [125].

\section{Conclusions}

The discovery of insulin heralded a new dawn for people with diabetes, with significant gains in both life expectancy and quality of life. The ultimate goal of insulin therapy is to mimic the physiological secretion of insulin to accommodate both fasting and prandial requirements, and advances in protein engineering have enabled the development of insulin analogs that mimic both basal and prandial requirements.

The structural characteristics underlying the physiological properties of insulin glargine define its clinical effectiveness. Data indicate that low solubility at physiological $\mathrm{pH}$ is a prerequisite, but this alone is not sufficient for a basal insulin analog. Instead, factors determining successful prolonged and continuous delivery of the analog are likely to include a balanced number of inter-hexamer interactions and moderate crystal stability.

Insulin glargine has demonstrated efficacy and consistent safety in numerous large randomized clinical studies, supporting its use as basal insulin therapy for the treatment of diabetes, in line with ADA/EASD recommendations. Insulin glargine continues to achieve real success in the clinical setting, providing important benefits to people with diabetes. Importantly, as glargine can be used in combination with other insulin and non-insulin antidiabetic agents, it has a central role to play in the tailoring of treatment on an individual basis, which is recognized as the most appropriate approach to the effective management of diabetes. 
In conclusion, the development and introduction of long-acting insulin analogs represented a dramatic step forward in diabetes care, fulfilling the clinical need for a basal insulin analog (which was hinted at by NPH insulin almost half a century previously). Insulin glargine now represents a reference basal insulin against which future developments in long-acting insulin analogs are measured [70, 126, 127].

Acknowledgments The authors are grateful to all members of the "New Insulins" team of former Hoechst AG. They thank Dr. Naoki Sakai (University of Lübeck) for help with Fig. 3. RH acknowledges support by the Chinese Academy of Sciences through a Visiting Professorship for Senior International Scientists (Grant no. 2010T1S6). Editorial support for this article was provided by Alexander Jones, Ph.D., from Medicus International, London, and funded by Sanofi.

Conflict of interest DO has received lecture fees and honoraria from Sanofi and Roche Diagnostics. GS and HB are employees of Sanofi. RH declares no conflict of interest.

Dedication The authors would like to dedicate this manuscript to the late Professor Geiger and the late Dr. Obermeier who were pioneers in the development of human insulin and insulin pumps.

The contents of this article and opinions expressed within are those of the authors, and it was the decision of the authors to submit the manuscript for publication. The authors conceived and critically reviewed the manuscript, including input into every stage of the development of the manuscript, and approved the final version for submission.

Open Access This article is distributed under the terms of the Creative Commons Attribution Noncommercial License which permits any noncommercial use, distribution, and reproduction in any medium, provided the original author(s) and the source are credited.

\section{References}

1. Owens DR. Human insulin. UK, Europe, USA: MTP Press; 1986.

2. Bliss M. The discovery of insulin: the inside story. Publ Am Inst Hist Pharm. 1997;16:93-9.

3. Joslin EP. The treatment of diabetes mellitus. Can Med Assoc J. 1916;6(8):673-84.

4. Mazur A. Why were "starvation diets" promoted for diabetes in the pre-insulin period? Nutr J. 2011;10:23. doi:10.1186/14752891-10-23.

5. Zajac J, Shrestha A, Patel P, Poretsky L. The main events in the history of diabetes mellitus. In: Poretsky L, editor. Principles of diabetes mellitus. New York: Springer Science + Business Media; 2010. p. 3-16.

6. Himsworth HP. Diabetes mellitus: Its differentiation into insulin-sensitive and insulin-insensitive types. Lancet. 1936;227(5864):127-30.

7. Papaspyros NS. Introduction. In: Verlag GT, editor. The history of diabetes mellitus. Stuttgart: Thieme; 1964. p. 1-10.

8. von Mering J, Minkowski O. Diabetes mellitus nach Pankreasexstirpation. Arch Exp Path Pharmakol. 1890;26:371-87.

9. Hédon E. Sur la consommation du sucre chez la chien après l'extirpation du pancreas. Arch Physiol Normal Pathol Vth Series. 1893;5:154-63.
10. Minkowski O. Historical development of the theory of pancreatic diabetes by Oscar Minkowski, 1929: introduction and translation by Rachmiel Levine. Diabetes. 1989;38(1):1-6.

11. Opie EL. The relation Oe diabetes mellitus to lesions of the Pancreas. Hyaline degeneration of the Islands Oe Langerhans. J Exp Med. 1901;5(5):527-40.

12. Opie EL. On the relation of chronic interstitial pancreatitis to the Islands of Langerhans and to diabetes melutus. J Exp Med. 1901;5(4):397-428.

13. Zülzer G. Ueber Versuche einer specifischen Fermenttherapie des Diabetes. Zeitschrift für die experimentelle Pathologie und Therapie. 1908;5(2):307-18.

14. Paulesco NC. Action de l'extrait pancréatique injecté dans le sang, chez un animal diabétique. CR Seanc Soc Biol (Paris). 1921;85:555-9.

15. Scott EL. On the influence of intravenous injections of an extract of the pancreas on experimental pancreatic diabetes. Am J Physiol. 1912;29:306-10.

16. Kleiner IS. The action of intravenous injections of pancreas emulsions in experimental diabetes. J Biol Chem. 1919;40:153-70.

17. Rennie J, Fraser T. The islets of Langerhans in relation to diabetes. Biochem J. 1907;2(1-2):7-19.

18. Kimball CP, Murlin JR. Aqueous extracts of pancreas: III. Some precipitation reactions of insulin. J Biol Chem. 1923;58:337-46.

19. Lasker SP, McLachlan CS, Wang L, Ali SMK, Jelinek HF. Discovery, treatment and management of diabetes. J Diabetol. 2010;1(1).

20. Rosenfeld L. Insulin: discovery and controversy. Clin Chem. 2002;48(12):2270-88.

21. de Leiva A, Brugues E, de Leiva-Perez A. The discovery of insulin: continued controversies after ninety years. Endocrinologia y nutricion : organo de la Sociedad Espanola de Endocrinologia y Nutricion. 2011;58(9):449-56. doi:10.1016/j. endonu.2011.10.001.

22. Paulesco NC. Traitement du diabete. La Presse Medicale; 1924.

23. Paulesco NC. Recherches sur le role du pancreas dans l'assimilation nutritive. Arch Int Physiol. 1921;17:85-109.

24. Paulesco NC. Quelques reactions chimiques et physiques appliquees a l'extrait aqueux du pancreas pour le debarrasser des substances proteiques en exces. Arch Int Physiol. 1923;21:71-85.

25. Paulesco NC. Divers procedes pour entroduire l'extrait pamcreatique dans l'organisme d'un animal diabetique. Arch Int Physiol. 1923;21:215-38.

26. Banting FG, Best $\mathrm{CH}$. The internal secretion of the pancreas. J Lab Clin Med. 1922;7:251-66.

27. Banting FG, Best CH, Collip JB, Campbell WR, Fletcher AA. Pancreatic extracts in the treatment of diabetes mellitus. Can Med Assoc J. 1922;12(3):141-6.

28. Barron M. The relation of the islets of Langerhans to diabetes with special reference to cases of pancreatic lithiasis. Surg Gynecol Obstet. 1920;31:437-48.

29. Banting FG, Best CH. Pancreatic extracts. J Lab Clin Med. 1922;7:464-72.

30. Chamoun D, Choi D, Tavares AB, Udoff LC, Levitas E, Resnick $\mathrm{CE}$, et al. Regulation of granulosa cell-derived insulin-like growth factor binding proteins (IGFBPs): role for protein kinase- $\mathrm{C}$ in the pre- and posttranslational modulation of IGFBP4 and IGFBP-5. Biol Reprod. 2002;67(3):1003-12.

31. von Horn H, Hwa V, Rosenfeld RG, Hall K, Teh BT, Tally M, et al. Altered expression of low affinity insulin-like growth factor binding protein related proteins in hepatoblastoma. Int $\mathbf{J}$ Mol Med. 2002;9(6):645-9.

32. Garber AJ, Davidson JA, Krosnick A, Beaser RS, Anderson JH Jr. Impact of transfer from animal-source insulins to 
biosynthetic human insulin (rDNA E coli) in patients with diabetes mellitus. Clin Ther. 1991;13(5):627-36.

33. Markussen J, Damgaard U, Jorgensen KH, Sorensen E, Thim L. Human monocomponent insulin. Chemistry and characteristics. Acta medica Scandinavica Supplementum. 1983;671:99-105.

34. Thim L, Hansen MT, Sorensen AR. Secretion of human insulin by a transformed yeast cell. FEBS Lett. 1987;212(2):307-12 (pii: 0014-5793(87)81366-2).

35. Nicol DS, Smith LF. Amino-acid sequence of human insulin. Nature. 1960;187:483-5.

36. Mirsky IA, Jinks R, Perisutti G. The Isolation and Crystallization of Human Insulin. J Clin Investig. 1963;42:1869-72. doi:10.1172/JCI104871.

37. Smith LF. Isolation of insulin from pancreatic extracts using carboxymethyl and diethylaminoethyl celluloses. Biochimica et biophysica acta. 1964;82:231-6.

38. Kimmel JR, Pollock HG. Studies of human insulin from nondiabetic and diabetic pancreas. Diabetes. 1967;16(10):687-94.

39. Brunfeldt K, Deckert T, Thomsen J. Human crystalline insulin from non-diabetic and diabetic patients. Acta endocrinologica. 1969;60(3):543-9.

40. Shapcott D, O'Brien D. A method for the isolation of insulin from single human pancreas. Diabetes. 1970;19(11):831-6.

41. World Health Organization. WHO Technical Report Series 565. Geneva1975.

42. Kreines K. The use of various insulins in insulin allergy. Arch Intern Med (Chicago). 1965;116:167-71.

43. Akre PR, Kirtley WR, Galloway JA. Comparative hypoglycemic response of diabetic subjects to human insulin or structurally similar insulins of animal source. Diabetes. 1964;13:135-43.

44. Orskov H, Christensen NJ. Plasma disappearance rate of injected human insulin in juvenile diabetic, maturity-onset diabetic and nondiabetic subjects. Diabetes. 1969;18(10):653-9.

45. Sonksen PH, Tompkins CV, Srivastava MC, Nabarro JD. A comparative study on the metabolism of human insulin and porcine proinsulin in man. Clin Sci Mol Med. 1973;45(5):633-54.

46. Deckert T, Andersen OO, Grundahl E, Kerp L. Isoimmunization of man by recrystallized human insulin. Diabetologia. 1972;8(5):358-61.

47. Sieber P, Kamber B, Hartmann A, Jöhl A, Riniker B, Rittel W. Totalsynthese von Humaninsulin unter gezielter Bildung der Disulfidbindungen. Vorläufige Mitteilung. Helvetica Chimica Acta. 1974;57(8):2617-21.

48. Marki F, Albrecht W. Biological activity of synthetic human insulin. Diabetologia. 1977;13(4):293-5.

49. Obermeier R, Geiger R. A new semisynthesis of human insulin. Hoppe-Seyler's Zeitschrift fur physiologische Chemie. 1976;357(6):759-67.

50. Homandberg GA, Mattis JA, Laskowski M Jr. Synthesis of peptide bonds by proteinases. Addition of organic cosolvents shifts peptide bond equilibria toward synthesis. Biochemistry. 1978;17(24):5220-7.

51. Owens DR, Vora JP, Heding LG, Luzio S, Ryder RE, Atiea J, et al. Human, porcine and bovine ultralente insulin: subcutaneous administration in normal man. Diabetic Med: J Br Diabet Assoc. 1986;3(4):326-9.

52. Best $\mathrm{CH}$. Prolongation of insulin action. Ohio J Sci. 1937;37(6):362-77.

53. Schlichtkrull J, Pingel M, Heding LG. Insulin preparations with prolonged effect. In: Hasselblatt A, Bruchhausen FV, editors. Handbook of experimental pharmacology. Berlin, Heidelberg, New York: Springer; 1975. p. 729-77.

54. Owens DR. Insulin preparations with prolonged effect. Diabetes Technol Ther. 2011;13(Suppl 1):S5-14. doi:10.1089/dia.2011. 0068 .
55. Bauman L. Clinical experience with globin insulin. Am J Med Sci. 1939;198(4):475-81.

56. Reiner L, Searle DS, Lang EH. On the hypoglycemic activity of globin insulin. J Pharmacol Exp Ther. 1939;67:330-40.

57. Umber F, Stoerring FK, Foellmer W. Erfolge mit einem neuartigen Depot Insulin ohne Protaminzusatz (Surfen-Insulin). Klin Woch. 1938;17:443-6.

58. Lepore M, Pampanelli S, Fanelli C, Porcellati F, Bartocci L, Di Vincenzo A, et al. Pharmacokinetics and pharmacodynamics of subcutaneous injection of long-acting human insulin analog glargine, NPH insulin, and ultralente human insulin and continuous subcutaneous infusion of insulin lispro. Diabetes. 2000;49(12):2142-8.

59. Chikama T, Nakamura M, Nishida T. Up-regulation of integrin alpha5 by a C-terminus four-amino-acid sequence of substance $\mathrm{P}$ (phenylalanine-glycine-leucine-methionine- amide) synergistically with insulin-like growth factor-1 in SV-40 transformed human corneal epithelial cells. Biochem Biophys Res Commun. 1999;255(3):692-7.

60. Fujita-Yamaguchi Y, Hawke DH, Shively JE, Choi S. Partial amino acid sequence analyses of human placental insulin receptor. Protein Seq Data Anal. 1987;1(1):3-6.

61. Matsumoto S, Isogai A, Suzuki A. N-terminal amino acid sequence of an insect neurohormone, melanization and reddish coloration hormone (MRCH): heterogeneity and sequence homology with human insulin-like growth factor II. FEBS Lett. 1985;189(1):115-8.

62. Bell SC, Keyte JW. N-terminal amino acid sequence of human pregnancy-associated endometrial alpha 1-globulin, an endometrial insulin-like growth factor (IGF) binding protein-evidence for two small molecular weight IGF binding proteins. Endocrinology. 1988;123(2):1202-4.

63. Rinderknecht E, Humbel RE. The amino acid sequence of human insulin-like growth factor I and its structural homology with proinsulin. J Biol Chem. 1978;253(8):2769-76.

64. Krayenbuhl C, Rosenberg T. Crystalline protamine insulin. Rep Steno Mem Hosp Nord Insulinlab. 1946;1:60-73.

65. Hagedorn HC. Protamine insulinate: (section of therapeutics and pharmacology). Proc R Soc Med. 1937;30(6):805-14.

66. Hallas-Moller K, Jersild M, Petersen K, Schlichtkrull J. The lente insulins, insulin-zinc suspensions. Danish Med Bull. 1954;1(5):132-42.

67. Whitehouse FW, Lowrie WL, Redfern E, Bryan JB. The lente insulin triad, with emphasis on the use of "lente combinations". Ann Intern Med. 1961;55:894-902.

68. Galloway JA, Bressler R. Insulin treatment in diabetes. Med Clin N Am. 1978;62(4):663-80.

69. White JR Jr., Campbell RK, Hirsch I. Insulin analogues: new agents for improving glycemic control. Postgrad Med. 1997;101(2):58-60, 3-5, 70.

70. Bergenstal RM, Rosenstock J, Arakaki RF, Prince MJ, Qu Y, Sinha VP, et al. A randomized, controlled study of once-daily LY2605541, a novel long-acting basal insulin, versus insulin glargine in basal insulin-treated patients with type 2 diabetes. Diabetes Care. 2012;35(11):2140-7. doi:10.2337/dc12-0060.

71. Rosenstock J, Bergenstal RM, Blevins TC, Morrow LA, Prince MJ, Qu Y, et al. Better glycemic control and weight loss with the novel long-acting basal insulin LY2605541 compared with insulin glargine in type 1 diabetes: a randomized, crossover study. Diabetes Care. 2013;36(3):522-8. doi:10.2337/dc12-0067.

72. Sanger F, Tuppy H. The amino-acid sequence in the phenylalanyl chain of insulin. 2. The investigation of peptides from enzymic hydrolysates. Biochem J. 1951;49(4):481-90.

73. Sanger F, Tuppy H. The amino-acid sequence in the phenylalanyl chain of insulin. I. The identification of lower peptides from partial hydrolysates. Biochem J. 1951;49(4):463-81. 
74. Adams MJ, Blundell TL, Dodson EJ, Dodson GG, Vijayan M, Bakar EN, et al. Structure of rhombohedral 2 zinc insulin crystals. Nature. 1969;224(5218):491-5.

75. Vajo Z, Duckworth WC. Genetically engineered insulin analogs: diabetes in the new millenium. Pharmacol Rev. 2000;52(1):1-9.

76. Brange J, Ribel U, Hansen JF, Dodson G, Hansen MT, Havelund $\mathrm{S}$, et al. Monomeric insulins obtained by protein engineering and their medical implications. Nature. 1988;333(6174):679-82. doi:10.1038/333679a0.

77. Markussen J, Diers I, Engesgaard A, Hansen MT, Hougaard P, Langkjaer L, et al. Soluble, prolonged-acting insulin derivatives. II. Degree of protraction and crystallizability of insulins substituted in positions A17, B8, B13, B27 and B30. Protein Eng. 1987;1(3):215-23.

78. Markussen J, Diers I, Hougaard P, Langkjaer L, Norris K, Snel $\mathrm{L}$, et al. Soluble, prolonged-acting insulin derivatives. III. Degree of protraction, crystallizability and chemical stability of insulins substituted in positions A21, B13, B23, B27 and B30. Protein Eng. 1988;2(2):157-66.

79. Markussen J, Hougaard P, Ribel U, Sorensen AR, Sorensen E. Soluble, prolonged-acting insulin derivatives. I. Degree of protraction and crystallizability of insulins substituted in the termini of the B-chain. Protein Eng. 1987;1(3):205-13.

80. Geiger R. Chemie des Insulins. Chemiker Zeitung. 1976;100: 111-29.

81. Jorgensen S, Vaag A, Langkjaer L, Hougaard P, Markussen J. NovoSol Basal: pharmacokinetics of a novel soluble long acting insulin analogue. Bmj. 1989;299(6696):415-9.

82. Zeuzem S, Stahl E, Jungmann E, Zoltobrocki M, Schoffling K, Caspary WF. In vitro activity of biosynthetic human diarginylinsulin. Diabetologia. 1990;33(2):65-71.

83. Monti LD, Poma R, Caumo A, Stefani I, Picardi A, Sandoli EP, et al. Intravenous infusion of diarginylinsulin, an insulin analogue: effects on glucose turnover and lipid levels in insulin-treated type II diabetic patients. Metab: Clin Exp. 1992;41(5):540-4.

84. Kemmler W, Peterson JD, Steiner DF. Studies on the conversion of proinsulin to insulin. I. Conversion in vitro with trypsin and carboxypeptidase B. J Biol Chem. 1971;246(22):6786-91.

85. Grau U. Inventor Hoechst Aktiengesellschaft, assignee. Pharmaceutical agent for the treatment of diabetes mellitus United States 1984.

86. Rhodes CJ. Processing of the insulin molecule. In: LeRoith D, Taylor SI, Olefsky JM, editors. Diabetes mellitus: a fundamental and clinical text. 3rd ed. London: Lippincott Williams \& Wilkins; 2004.

87. Berchtold H, Hilgenfeld R. Binding of phenol to R6 insulin hexamers. Biopolymers. 1999;51(2):165-72. doi:10.1002/ (SICI) 1097-0282(1999)51:2<165:AID-BIP6>3.0.CO;2-X.

88. Derewenda U, Derewenda Z, Dodson EJ, Dodson GG, Reynolds CD, Smith GD, et al. Phenol stabilizes more helix in a new symmetrical zinc insulin hexamer. Nature. 1989;338(6216): 594-6. doi:10.1038/338594a0.

89. Brange J, Skelbaek-Pedersen B, Lankjaer L, Damgaar U, Ego H, Havelund S, et al. Galenics of insulin preparations. In: Berger M, editor. Subcutaneous insulin therapy. Berlin, Heidelberg: Springer; 1985.

90. Seipke G, Geisen K, Neubauer H-P, Pittius C, Rosskamp R, Schwabe D. New insulin preparations with prolonged action profiles: A21-modified arginine insulins [abstract]. Diabetologia. 1992;35(Suppl. 1):A4.

91. Seipke G, Berchtold H, Geisen K, Hilgenfeld R, Rosskamp R. HOE 901: a new insulin with prolonged action [abstract]. Eur J Endocrinol. 1995;132(Suppl. 1):25.

92. Hilgenfeld R, Sicker T, Dörschug M, Obermeier R, Geisen K, Seipke G, et al. Controlling insulin bioavailability by crystal contact engineering. Diabetologia. 1992;35(Supplement):A193.
93. Pieber TR, Eugene-Jolchine I, Derobert E. Efficacy and safety of HOE 901 versus NPH insulin in patients with type 1 diabetes. The European Study Group of HOE 901 in type 1 diabetes. Diabetes Care. 2000;23(2):157-62.

94. HOE 901/2004 Study Investigators Group. Safety and efficacy of insulin glargine (HOE 901) versus NPH insulin in combination with oral treatment in Type 2 diabetic patients. Diabet Med: J Br Diabet Assoc. 2003;20(7):545-51.

95. Rosenstock J, Park G, Zimmerman J, Group, USIGTDI. Basal insulin glargine (HOE 901) versus NPH insulin in patients with type 1 diabetes on multiple daily insulin regimens. U.S. Insulin Glargine (HOE 901) Type 1 Diabetes Investigator Group. Diabetes Care. 2000;23(8):1137-42.

96. Owens DR, Coates PA, Luzio SD, Tinbergen JP, Kurzhals R. Pharmacokinetics of 125I-labeled insulin glargine (HOE 901) in healthy men: comparison with NPH insulin and the influence of different subcutaneous injection sites. Diabetes Care. 2000;23(6):813-9.

97. Owens DR. Optimizing treatment strategies with insulin glargine in Type 2 diabetes. Expert Rev Endocrinol Metab. 2012;7(4):377-93.

98. Bolli GB, Frick A, Schmidt R, Eisenblaetter T, Becker R. Plasma concentrations of insulin glargine and its metabolites after SC injection of glargine in subjects with type 1 diabetes. ADA 71st Scientific Sessions; June 24-28, 2011; San Diego, CA. Abstract 71-OR2011.

99. Lucidi P, Portcellati F, Rossetti P, Candeloro P, Andreoli AM, Frick A et al. Metabolism of insulin glargine after subcutaneous injection of therapeutic dose in type 2 diabetes mellitus. ADA 71st Scientific Sessions; June 24-28, 2011; San Diego, CA. Abstract 1092-P2011.

100. Werner U, Schmidt R, Blair E, Renna SM, Tennagels N. The molecular mechanism of insulin glargine metabolism in vivo. ADA 72nd Scientific Sessions; June 8-12, 2012; Philadelphia, PA. Abstract 1645-P2012.

101. Porcellati F, Rossetti P, Ricci NB, Pampanelli S, Torlone E, Campos SH, et al. Pharmacokinetics and pharmacodynamics of the long-acting insulin analog glargine after 1 week of use compared with its first administration in subjects with type 1 diabetes. Diabetes Care. 2007;30(5):1261-3. doi:10.2337/dc06-2208.

102. Inzucchi SE, Bergenstal RM, Buse JB, Diamant M, Ferrannini E, Nauck M, et al. Management of hyperglycemia in type 2 diabetes: a patient-centered approach: position statement of the American Diabetes Association (ADA) and the European Association for the Study of Diabetes (EASD). Diabetes Care. 2012;35(6):1364-79. doi:10.2337/dc12-0413.

103. Heinemann L, Linkeschova R, Rave K, Hompesch B, Sedlak M, Heise T. Time-action profile of the long-acting insulin analog insulin glargine (HOE901) in comparison with those of NPH insulin and placebo. Diabetes Care. 2000;23(5):644-9.

104. Ratner RE, Hirsch IB, Neifing JL, Garg SK, Mecca TE, Wilson CA. Less hypoglycemia with insulin glargine in intensive insulin therapy for type 1 diabetes. U.S. Study Group of Insulin Glargine in Type 1 Diabetes. Diabetes Care. 2000;23(5):639-43.

105. Home P. Insulin glargine: the first clinically useful extendedacting insulin in half a century? Expert Opin Investig Drugs. 1999;8(3):307-14. doi:10.1517/13543784.8.3.307.

106. Sommerfeld MR, Muller G, Tschank G, Seipke G, Habermann $\mathrm{P}$, Kurrle R, et al. In vitro metabolic and mitogenic signaling of insulin glargine and its metabolites. PloS one. 2010;5(3):e9540. doi:10.1371/journal.pone.0009540.

107. Blin P, Lassalle R, Dureau-Pournin C, Ambrosino B, Bernard MA, Abouelfath A, et al. Insulin glargine and risk of cancer: a cohort study in the French National Healthcare Insurance Database. Diabetologia. 2012;55(3):644-53. doi:10.1007/ s00125-011-2429-5. 
108. Owens DR. Glargine and cancer: can we now suggest closure? Diabetes Care. 2012;35(12):2426-8. doi:10.2337/dc12-1968.

109. Home PD, Lagarenne P. Combined randomised controlled trial experience of malignancies in studies using insulin glargine. Diabetologia. 2009;52(12):2499-506. doi:10.1007/s00125-0091530-5.

110. Investigators OT, Gerstein HC, Bosch J, Dagenais GR, Diaz R, Jung $\mathrm{H}$, et al. Basal insulin and cardiovascular and other outcomes in dysglycemia. N Engl J Med. 2012;367(4):319-28. doi:10.1056/NEJMoa1203858.

111. Ashwell SG, Gebbie J, Home PD. Optimal timing of injection of once-daily insulin glargine in people with Type 1 diabetes using insulin lispro at meal-times. Diabet Med: J Br Diabet Assoc. 2006;23(1):46-52. doi:10.1111/j.1464-5491.2005.01726.x.

112. Riddle MC, Rosenstock J, Gerich J, Insulin Glargine Study I. The treat-to-target trial: randomized addition of glargine or human NPH insulin to oral therapy of type 2 diabetic patients. Diabetes Care. 2003;26(11):3080-6.

113. Owens DR, Luzio SD, Sert-Langeron C, Riddle MC. Effects of initiation and titration of a single pre-prandial dose of insulin glulisine while continuing titrated insulin glargine in type 2 diabetes: a 6-month 'proof-of-concept' study. Diabetes, Obes Metab. 2011;13(11):1020-7. doi:10.1111/j.1463-1326.2011. 01459.x.

114. Hollander P, Cooper J, Bregnhoj J, Pedersen CB. A 52-week, multinational, open-label, parallel-group, noninferiority, treatto-target trial comparing insulin detemir with insulin glargine in a basal-bolus regimen with mealtime insulin aspart in patients with type 2 diabetes. Clin Ther. 2008;30(11):1976-87. doi:10. 1016/j.clinthera.2008.11.001.

115. Meier JJ. GLP-1 receptor agonists for individualized treatment of type 2 diabetes mellitus. Nat Rev Endocrinol. 2012;8(12):728-42. doi:10.1038/nrendo.2012.140.

116. Riddle M, Home P, Marre M, Niemoeller E, Ping L, Rosenstock J. Efficacy and safety of once-daily lixisenatide in Type 2 diabetes insufficiently controlled with basal insulin \pm metformin: GetGoal-L study. Diabetes. 2012;61(Supplement 1):983-P (A251).

117. Rosenstock J, Forst T, Aronson R, Sau-que-reyna L, Souhami E, Ping $L$ et al. Efficacy and safety of once-daily lixisenatide added on to titrated glargine plus oral agents in Type 2 diabetes: GetGoal-Duo 1 Study. Diabetes. 2012;61(Supplement 1):62-OR (A18).

118. Seino Y, Min KW, Niemoeller E, Takami A, Investigators EGLAS. Randomized, double-blind, placebo-controlled trial of the once-daily GLP-1 receptor agonist lixisenatide in Asian patients with type 2 diabetes insufficiently controlled on basal insulin with or without a sulfonylurea (GetGoal-L-Asia). Diabetes,
Obes Metab. 2012;14(10):910-7. doi:10.1111/j.1463-1326. 2012.01618.x.

119. Petznick A. Insulin management of Type 2 diabetes mellitus. Am Fam Physician. 2011;84:183-90.

120. Brandle M, Azoulay M, Greiner RA. Cost-effectiveness and cost-utility of insulin glargine compares with NPH insulin nased on a 10-year simulation of long-term complications with the Diabetes Mellitus Model in patients with type 2 diabetes in Switzerland. Int J Clin Pharmacol Ther. 2007;45:203-20.

121. Pfohl M, Schädlich PK, Dippel FW, Koltermann KC. Health economic evaluation of insulin glargine vs NPH insulin in intensified conventional therapy for type 1 diabetes in Germany. J Med Econ. 2012;15(Suppl 2):14-27.

122. Gordon J, Evans M, McEwan P, Bain S, Vora J. Evaluation of insulin use and value for money in Type 2 diabetes in the United Kingdom. Diabetes Ther. 2013;4:51-66.

123. Cameron CG, Bennett HA. Cost-effectiveness of insulin analogues for diabetes mellitus. CMAJ. 2009;180:400-7.

124. Monami M, Marchionni N, Mannucci E. Long-acting insulin analogues vs. NPH human insulin in type 1 diabetes. A metaanalysis. Diab Obes Metab. 2009;11:372-8.

125. Wang L, Wei W, Miao R, et al. Real-world outcomes of US employees with type 2 diabetes mellitus treated with insulin glargine or neutral protamine Hagedorn insulin: a comparative retrospective database study. BMJ Open. 2013;3:e002348.

126. Garber AJ, King AB, Del Prato S, Sreenan S, Balci MK, MunozTorres $\mathrm{M}$, et al. Insulin degludec, an ultra-longacting basal insulin, versus insulin glargine in basal-bolus treatment with mealtime insulin aspart in type 2 diabetes (BEGIN Basal-Bolus Type 2): a phase 3, randomised, open-label, treat-to-target noninferiority trial. Lancet. 2012;379(9825):1498-507. doi:10. 1016/S0140-6736(12)60205-0.

127. Heller S, Buse J, Fisher M, Garg S, Marre M, Merker L, et al. Insulin degludec, an ultra-longacting basal insulin, versus insulin glargine in basal-bolus treatment with mealtime insulin aspart in type 1 diabetes (BEGIN Basal-Bolus Type 1): a phase 3, randomised, open-label, treat-to-target non-inferiority trial. Lancet. 2012;379(9825):1489-97. doi:10.1016/S0140-6736(12)60204-9.

128. Yang Y, Hua QX, Liu J, Shimizu EH, Choquette MH, Mackin $\mathrm{RB}$, et al. Solution structure of proinsulin: connecting domain flexibility and prohormone processing. J Biol Chem. 2010;285(11):7847-51. doi:10.1074/jbc.C109.084921

129. Smith GD, Pangborn WA, Blessing RH. The structure of T6 human insulin at $1.0 \mathrm{~A}$ resolution. Acta Crystallogr D Biol Crystallogr. 2003;59:474-82.

130. Takiya L, Dougherty T. Pharmacist's guide to insulin preparations: a comprehensive review. Last accessed August 2012. https://secure.pharmacytimes.com/lessons/200510-03.asp. 